UDC 262.12:929 Ivan V.

Снежана Божанић

Оригиналан научни рад

Милица Кисић

примљено: 1. јун 2012

Универзитет у Новом Саду

прихваћено: 1. октобар 2012

Филозофски факултет

Одсек за историју

sbozanic5@gmail.com

nekmoli@orion.rs

\title{
О ИВАНУ ВИТЕЗУ ОД СРЕДНЕ У ДЕЛУ RERUM UNGARICARUM DECADES*
}

Сажетак: У раду се прати казивање Антонија Бонфинија, у делу Rerum Ungaricarum Decades, decas IV, о Ивану Витезу од Средне. Рад је хронолошки прецизно омеђен, од дана крунисања Матије Корвина до смрти Ивана Витеза од Средне. Вести о острогонском надбискупу и умном хуманисти се налазе у прве три књиге, наведеног дела. Прва књига доноси податке о обраћању краља Матије Ивану Витезу након крунисања, потом о његовом именовању за острогонског надбискупа, бележи се његова активност у вези са устанком у Трансилванији и Молдавији и истиче се његов значај као ученог нотара. Друга књига, сведочи да се Иван 1468. налазио у Матијиној пратњи, током рата са Чесима. Трећа књига дела Rerum Ungaricarum Decades, decas IV детаљно говори о уроти против краља Матије, на чијем челу су се налазили острогонски надбискуп и његов сестрић. Наводе се разлози који су навели Ивана Витеза од Средне да се придружи завереницима, прати се ток завере, његово измирење са угарским краљем и смрт. У посебном пасусу се набрајају Витезове заслуге, које је учинио, на пољу културе за средњовековну Угарску.

Кључне речи: Иван Витез од Средне, Антоније Бонфини, угарски краљ Матија Корвин, Острогон, завера.

До снажног процвата хуманизма и ренесансе, у средњовековној Угарској, дошло је за време владавине краља Матије Корвина (1458-1490). Након женидбе са Беатриче Арагонском, ${ }^{1}$ на његовом двору обновљено је занимање за античку прошлост и вредности, раширена је употреба латинског језика, изучава се класична књижевност, те је подстакнут развој индивидуалистичког и критичког духа. ${ }^{2}$

\footnotetext{
* Рад представља фазни резултат истраживања за два пројекта: Војвођански простор у контексту европске историје (бр. 177002) финансиран од стране Министарства просвете и науке Владе Републике Србије и Средњовековна насеља на тлу Војводине. Историјски прочеси и догађаји, бр. Решења 114-4512216/2011, који финансира Покрајински секретаријат за науку Владе Аутономне покрајине Војводине.

${ }^{1}$ Она је била кћи напуљског краља Феранта (Фердинада) Арагонског (1458-1494).

${ }^{2}$ На двору краља Матије деловали су познати књижевници, научници и уметници, првенствено из Италије али и околних земаља. Између осталих, ту су боравили и радили: књижевник Galeotto Marzio
} 
Међутим, прве хуманистичке идеје у Угарску су донели Иван Витез од Средне и Иван Чесмички.

Италијански хуманиста и књижњвник Антоније Бонфини из Асколија, у прве три књиге дела Rerum Ungaricarum Decades, decas IV, доноси значајне и занимљиве податке о Ивану Витезу од Средне. ${ }^{3}$

Чувени угарски и хрватски хуманиста, латиниста и писац, варадински бискуп, острогонски надбискуп, васпитач, одгајатељ и поочим Матије Корвина, математичар и астролог, ујак Јануса Панонијуса, Иван Витез од Средне (Johannes Vitéz de Zredna) рођен је 1405 . године у Средни, у Крижевачкој жупанији. ${ }^{4}$ Потицао jе из породице „Geleth de Zredna“ или Гјелетић од Средне. ${ }^{5}$ Његов отац је био близак сарадник Јанка Хуњадија, гувернера Угарске (1446-1452). Широко и свестрано образовање стекао је за време студирања у Бечу, Болоњи и Падови. ${ }^{6}$

Током боравка у иностранству, упознао је чувене хуманисте чије су идеје пресудно утицале на његове ставове, филозофске погледе и оријентацију. Енеа Силвије Пиколомини, потоњи папа Пије II (1458-1464), умни хуманиста и библиофил, којег је упознао током усавршавања у Италији, остао је у контакту са Витезом све до своје смрти. ${ }^{7}$ Ту су још Гргур Саночки, Мартин Крол, Гуарини Млађи и многи други.

По повратку у Угарску 1436. обављао је службу нотара а потом је постао каноник-кустос загребачког каптола. Имао је срећу да се упозна и интезивно дружи са Петром Павлом Вергеријем (1370-1444), који је крај живота провео на двору у

(Галеото Марцио) из Напуља, вајар Иван Дукновић Трогиранин (Iohannes Dalmata), астроном Regiomontanus (Јохан Милер из Баварске), астролог Marcin Bylica (1433-1493) из Пољске, астролог Peuerbach, минијатуристи Атаванти Атаванте и Naldo Naldi (Налдо Налди) из Италије, Феликс Петранчић из Дубровника, и многи други. Опширније погледати: J. Huszti, Janus Pannonius asztrologiai álláspontja, Minerva (Budapest), 5 (1927), 43-58; K. Prijatelj, Ivan Duknović, Zagreb 1957; P. Hanák, Povijest Mađarske, Zagreb 1995, 60-62.

${ }^{3}$ Бонфини у Угарску долази након Матијине женидбе са Беатриче. Није имао част да упозна Ивана Визета од Средне, јер је он умро 1472. године. G. Amado, La vita e l'opera di Antonio Bonfini, primo storico della nazione ungherese in generale e di Mattia Corvino in particolare, Montalto Marche 1930; A. Bonfinis, Rerum Ungaricarum Decades, tomus IV - pars II, ediderunt: Margarita Kulcsar et Petrus Kulcsar, Akademiai Kiado, Budapest 1976.

${ }^{4}$ Опширније погледати: V. Fraknói, Vitéz Janos püspök élete, Budapest 1871; V. Fraknói, Vitéz Janos esztergomi érsek élete, Budapest 1879; T. Kardos, A magyarorszagi humanizmus kora, Budapest 1955; V. Gortan, Hrvatski latinisti I, Zagreb 1969-1970; I. Tóth, Die Genealogie von Janus Pannonius, Acta Litteraria Academiae scientiarum Hungaricae, t. 14, br. 3-4, Budapest 1972, 377-387.

${ }^{5}$ Мирослав Курелац је објавио више радовима у којима се пре свега занима за културну и научну делатност Ивана Витеза. Погледати опширније: M. Kurelac, Kulturna i znanstvena djelatnost Ivana Viteza od Sredne, Zbornik Zavoda za povijesne znanosti IC Jugoslavenske akademije 12, Zagreb 1982, 24; M. Kurelac, Hrvatski humanisti rane renesanse, Croatica Christiana periodica 19, Zagreb 1987, 95-107; M. Kurelac, Ivan Vitez od Sredne i Jan Panonije (Ivan Česmički) između anarhije i tiranije, Mogućnosti 1-2 (1990), 182.

${ }^{6}$ Иван Витез од Средне је преводио Птоломеја са грчког језика (Magnae Compositionis libri).

${ }^{7}$ K. Pájorin, Enea Silvio Piccolomini ed i primi umanisti ungheresi. Rapporti e scambi tra Umanesimo italiano ed Umanesimo europeo, Milano 2001, 649-656. 
Будиму. Његове хуманистичке идеје су, свакако, позитивно утицале на младог Витеза, који се тек вратио са школовања у иностранству. ${ }^{8}$

Због широког образовања, Витез постаје васпитач и одгајатељ синова Јанка Хуњадија, Ладислава и Матије. Пресудно је утицао и на образовање, сина своје сестре Барбаре, Ивана Чесмичког (1434-1472). ${ }^{9}$ Захваљујући ујаку, Чесмички је једанаест година проверо на школовању у Ферари и Падови. Свог сестрића је, као дечака, 1447. године послао у чувену Гуаринијеву школу, која се налазила у Ферари (1447-1454). Врло брзо и без већих потешкоћа Чесмички је савладао латински и грчки језик. Суздржани, Иван Витез није крио одушевљење његовим напретком. ${ }^{10} \mathrm{У}$ периоду од 1454. до 1458. године, Чесмички је студирао у Падови где је стекао докторат из канонског права.

Каријера Ивана Витеза је све време ишла узлазном линијом. Године 1445. постао је бискуп Великог Варадина. Након тога учествује у бројним војним, политичким и дипломатским мисијама.

Већ у другом пасусу дела Rerum Ungaricarum Decades, tomus IV - pars II, аутор говори о варадинском бискупу Ивану Витезу. Наиме, краљ Матија је свечано крунисан „круном св. Стефана” 29. марта 1464. године. Управо је, Иван Витез одиграо значајну улогу у преговорима са Фридрихом III око враћа круне св. Стефана, коју је поменути владар држао код себе двадесетак година. Бонфини, посебно истиче да је краљ Матија том приликом варадинском бискупу Ивану и његовим потомцима даривао изузетну и богату Бихорску жупанију. Матија се тада одабраним речима обратио свом учитељу. На овом месту, аутор убацује, у стилу античких писаца, говор краља Матије. Изричита жеља Матијиног оца на самрти је била да Иван постане старатељ његов сина. Учитељ и ученик су све подједнако делили, добро и зло. Иван је био његова узданица, како саветима тако и подвигом, у отаџбини и ван ње. Није пропустио да нагласи његову деликатну и значајну улогу посредника и легата у преговорима око враћања свете круне. Поред тога, Иван Витез је као саборац пратио Матију и учествовао у ратним походима, у Чешкој, Турској, Трансилванији и Босни. Због свих набројаних подвига Матија говори да он и „чланови Сената додељу Ивану Витезу и наследницима Бихорску жупанију као вечити посед, како би наставио да још лагодније и верно обавља своје дужности и

\footnotetext{
${ }^{8}$ Вергерије Старији, књижњвник, почетком петнаестог века је написао познато дело De ingenuis moribus et liberalibus studiis adulescentiae, које представља значајну прекретницу у филозофском схватању одгоја. S. Tuksar, Glazbeno-teoretski fragmenti dvaju hrvatskih autora srednjeg veka: Hermana Dalmatinca i Petra Pavla Vergerija, Zbornik radova Četvrtog simpozijuma iz povijesti znanosti, Zagreb 1983, 101-102.

${ }^{9}$ Из обимне литературе о Ивану Чесмичком погледати опширније: S. Teleki, Narratio nostra et brevis expositio de vita Iani Pannonii. Iani Pannonii Opusculorum pars altera.Traiecti ad Rhenum, 1784, 161-242; I. Kukuljević Sakcinski, Ivan Česmički, Glasoviti hrvati prošlih vjekova, Zagreb 1886, 1-19; J. Huszti, Janus Pannonius, Péch 1931; L. Pongracz, Vespasiano da Bisticci ed i suoi clienti ungheresi. Annuario 1 (1939), 229247; T. Kardos, Janus Pannonius, Poet of the Hungarian Renaissance, New Hungarian Quarterly 14 (1973), 7993; J. Ślaski, Janus Pannonius et les Polonais, Acta litteraria Academiae scientiarum Hungaricae 15 (1973), 430-435; M. D. Birnbaum, Janus Pannonius - Poet and Politician, Zagreb 1981; M. D. Birnbaum, Humanists in a Shattered World. Croatian and Hungarian Latinity in the Sixteenth Century. Columbus (Ohio) 1986, 48-76. ${ }^{10}$ O. Perić, Tragom Ivana Česmičkog u pismima Ivana Viteza od Sredne, Mogućnosti 1-2 (1990), 125-132.
} 
како се лично побринуо да његова врлина не прође без награде и захвалности које завређује". ${ }^{11}$

Неколико дана након крунисања, краљ Матија је потврдио Златну булу Андрије II и декрете краља Лудовика I и Жигмунда. Том приликом донета је и одредба по којој владар није смео осудити ниједног поданика ради невере или велеиздаје. $^{12}$ Време и догађаји ће показати да се Матија Хуњади Корвин оглушио о многа обећања која је том приликом дао.

Други пут, Бонфини помиње Ивана Витеза у вези са његовим именовањем за острогонског надбискупа. Након двомесечне опсаде Зворника, краљ Матија је у другој половини 1464. године борави у Сегедину, где је организован сабор. Између осталих, сабору су присуствовали тадашњи острогонски надбискуп Дионизије Сеч (који је крунисао угарског краља), палатин Михаило Орсаг и Витезов сестрић Иван Чесмички. Детаљну причу о припреми делегације која је требала да путује у Рим, Бонфини кратко прекида и доноси вест да је те зиме умро Дионизије Сеч „човек уистину вредан хвале и сећањ $a^{\prime \prime}{ }^{13}$ Пошто је Иван Витез напустио дужност варадинског бискупа, због бројних заслуга и узорне оданости, Матија га је поставио за новог острогонског надбискупа. Његово именовање су, према речима италијанског хуманисте, ,племство и ирква прихватили уз велико одобрење”. ${ }^{14}$

Током 1467. године избила је побуна у Трансилванији и Молдавији. Реформа пореза, марта 1467. о којој Бонфини не говори у свом делу, укидање дотадашњих давања lucrum camerae regiae и тридесетине, те увођење намета крунске коморе (tributum fisci regalis, proventus fisci regalis) и намета крунске царине (vectigal sacrae coronae), изазвала је опште незадовољство становништва, сељаштва и племства. ${ }^{15}$ Током похода на Трансилванију дошло је до разлаза између краља

\footnotetext{
${ }^{11}$ A. Bonfinis, Rerum Ungaricarum Decades, tomus IV - pars II, 1: „Illud nequaquam omiserim, quod in referende gratie monumentum inter coronandum fecit. Ioannem Varadiensem episcopum de patre deque se iuxta bene meritum amplissimo illo ditissimoque comitatu perpetuo donavit, ut ipse posterique pontifices legitime fruerentur. Qua quidem donatione basilica Varadiensis dive genetrici a divo Ladislao rege dicata plurimum aucta et ditata est. Privilegium Mathias alto solio presidens, sacra corona, sceptro pomoque conspicuus proprio ore protulit. Id tale fuit: Cum Ioannes Vitesius, cui pater moriens nos unice commendavit, nobiscum utranque fortunam subire non recusarit, pari quoque discrimine nobiscum in captivitatem inciderit, liberarit Bohemico carcere, domi forisque nobis consilio, labore, opera semper affuerit, dissensiones et bella represserit, in Bohemica, Turcica, Transylvana et Bosnensi expeditione vel sua presentia vel copiarum auxiliis nunquam nostra castra deseruerit et salutari demum legationis officio gravissima queque negotia feliciter egerit coronanque nunc sacram longo postliminio retulerit, placet nobis patribusque conscriptis eum successoresque suos ob singularem, qua in divam genetricem et Ladislai numen afficimur, religionem comitatu Bihoriensi perpetuo donare, ut eadem fidelidatis officia commodius continuare possit et nos evitata ingratitudinis nota haud indebita virtuti premia persolvamus".

12 Опширније погледати: В. Krnic, Judicium generale (opći sud) u Ugarskoj i Hrvatskoj, Vjesnik HAD IX (1906-1907), 27-28; V. Klaić, Povijest Hrvata, od najstarijih vremena do svršetka XIX stoleća IV, Zagreb 1973, 65-66.

${ }^{13}$ Острогонски надбискуп Дионизије Сеч је умро 1. фебруара 1465. године.

${ }^{14}$ A. Bonfinis, Rerum Ungaricarum Decades, tomus IV - pars II, 4.

${ }^{15}$ П. Рокаи-3. Ђере-Т. Пал-А. Касаш, Историја Мађара, Београд 2002, 162 (П. Рокаи).
} 
Матије и војсковође Емерика Сепешког, који је напустио војни логор. ${ }^{16}$ Он је својевремено био најближи сарадник Корвиновог оца. Емерика је посебно изиритирала бесмислена погибија Михаила Силађија, те је почео отворено да говори о издаји и одметништву. Матија је знао да човека од таквог угледа не сме изгубити, те је послао острогонског надбискупа Ивана „да отклони његове сумье и поново успостави пређашње пријатељство", у чему је он и успео. ${ }^{17}$ Дакле, Иван Витез је вршио важне преговоре и мировна посредовања.

Истовремено са немирима у Трансилванији дошло је и до устанка у Молдавији, крајем 1467. године. Бонфини детаљно пише о походу краља Матије на Молдавију и његовом исходу. ${ }^{18}$ На челу Молдавије тада се налазио војвода Стефан Велики (Stefan-cel-Mare), који ће се касније прославити својим борбама против Турака. ${ }^{19}$ Не улазећи у детаље ових сукоба, јер то није тема овог рада, интересантно је напоменути да је краља Матију који још није прошао Карпате, на повратку из Молдавије, у једном селу изненада дочекао војсковђа Емерик са најбољим делом своје војске. Бонфини, поново, истиче да је Матију и Емерика, нешто раније, измирио Иван, надбискуп Острогона. ${ }^{20}$

Италијански хуманиста на том месту додаје да је краљ Матија тада имао два секретара, чувена по правичности и озбиљности: „Ioannes Strigoniensis et Stephanus Colociensis”. ${ }^{21}$ Обојица су били носиоци краљевог печата, са правом да састављају повеље и даровнице (,барем оне у којима није било никаквих спорних тачака").

За Ивана Витеза се, између осталог, може рећи да је био оснивач модерне државне канцеларије, коју су чинили учени и образовани људи, пре свега хуманисти. $^{22}$ Још у доба Јанка Хуњадија, Витез је као пронотар писао бројна писма која су стизала на удаљене европске дворове. Из тог периода (1445-1451) сачувано је 80 Витезових писама која су објављена под називом Епистолариј. ${ }^{23}$ У периоду од

\footnotetext{
${ }^{16}$ A. Bonfinis, Rerum Ungaricarum Decades, tomus IV - pars II, 14: ,Unum erat, quod in ea expeditione regem vehementer angebat, Emerici Scepusiensis indignatio, qui in hac expeditione regia castra deseruerat. Causa nemini satis comperta fuit, sed illud omnium ferebat opinio regem iam optimatibus formidolosum esse cepipse, suo, non alieno ductu agi velle, tacitam a cunctis proceribus reverentiam promptissimumque obsequium sibi postulare; Emericum inter paternos amicos primarium, quem tantopere cunctis honoribus evexerat, libere loquentem aut consiliis adversantem minis quandoque corripuisse; fecisse illi stomachum et hinc Michaelis exemplo illum plerumque metum incessisse; intercessisse quoque calumnias invidorum, qui parvi ab illo regem fieri dicerent, quin etiam illum sese rege maiorem ducere. Proinde oborta hinc simultas et suspicio veterem amicitiam interturbare ceperat”.

${ }^{17}$ Исто, 15.

${ }^{18}$ A. Bonfinis, Rerum Ungaricarum Decades, tomus IV-pars II, 16-17.

${ }^{19}$ Детљније погледати: N. Jorga, Istoria lui Stefan-Cel-Mare, Bucuresti 1904; В. Стефановић, Краљ Матија према Влашкој и Босни, ЛМС, година CVI, књига 331, свеска 1-3, јануар-март 1932, стр. 173-197; Н. Јорга, Историја Румуна и њихове цивилизачије, Вршац 1934.

${ }^{20}$ A. Bonfinis, Rerum Ungaricarum Decades, tomus IV - pars II, 18.

${ }^{21}$ Исто, 18.

${ }^{22}$ M. Kurelac, Kulturna i znanstvena djelatnost Ivana Viteza od Sredne, 23.

${ }^{23}$ Iohannis de Zredna Cancellariae Regis Hungariae olim Prothonotanii Epistolae, in diversis negotiis statum publicum Regni Hungariae concernentibus, ab anno Christi MCDXLV usque ad annum MCDLI etc. per Paulum de Iwanich, dioeceseos Zagrabiensis Presbyterum, altaris S. Pauli in Ecclesia Waradiensi Rectorem et
} 
1440. до 1472. настало је још 48 његових писама. ${ }^{24}$ Она говоре о политичким, друштвеним и културним приликама доба у којем је Витез живео и радио. ${ }^{25}$ Писана су по узору на античке писце, што је иначе било својствено хуманистима. ${ }^{26}$

Друга књига, италијанског писца, доноси веома значајан и често цитиран податак за српску историографију. У пратњи краља Матије 1468. године, током рата са Чесима, налазили су се, између осталих, деспот Вук, острогонски надбискуп и његов сестрић. ${ }^{27}$

Највећи део треће књиге дела Rerum Ungaricarum Decades, decas IV, аутор посвећује завери против краља Матије. Наиме, пре него што се упустио у детаљно описивање уроте, Бонфини за Матију бележи „да никада није имао мира - ратовао је без прекида и све до самог краја више задовољства налазио у оружју него у спокоју”. ${ }^{28}$ Он је увек настојао да одржи слогу у земљи, субјективан је писац, и да ратује искључиво ван ње. Међутим, дешавало се да буде суочен са заверама и издајама сопствених племића. Матија „достојан једног Херакла” често је стављан пред тешке задатке али „га срећа никад није напустила”. ${ }^{29}$

Док је Матија 1471. године био заокупљен чешким проблемом, домаћи племићи и свештенство уротили су се против њега. У земљу су довели Казимира, другог сина истоименог владара, са циљем да га прогласе за новог краља Угарске и уз помоћ пољске војске прогнају Матију.

На челу завере, налазили су се острогонски надбискуп Иван Витез од Средне „Матијин поочим и васпитач” и печујски бискуп Иван Чесмички. „Да се није бавио политиком, испао би од юега изванредан литерата достојан античких мајстора", додаје нешто касније у тексту Бонфини за Чесмичког. ${ }^{30}$ Од завереника, Бонфини једино још помиње Емерика Сепешког, који се, својевремено, пре похода на Трансилванију, већ био једном одметнуо од угарског краља (о чему се већ писало и у овом раду). ${ }^{31}$ По Бонфинију, Емерик Сепешки је том приликом рекао: „Истина,

Cancellariae Regiae olim Notarium, in. Schwandtner, Scriptores Rerum Hungaricarum Veteres ac Genuini, vol II, Impensis J. P. Kraus, Bibliopolae Vindobonensis 1746, str. 3-106; I. Boronkai, Iohannes Vitez de Zredna Opera quae supersunt, Akadémiai Kiadó, Budapest 1980, 27-168.

${ }^{24}$ V. Fraknói, Vitéz Janos esztergomi érsek élete, Budapest 1879; I. Boronkai, Iohannes Vitez de Zredna Opera quae supersunt, 169-224.

${ }^{25}$ Опширније погледати: O. Perić, Zbirka pisama Ivana Viteza od Sredne, Živa antika, god. XXIX, sv. 1, Skoplje 1979, 99-111; O. Perić-J. Paro, Uspon mirnog čovjeka - Ivan Vitez, Zagreb 1979; O. Perić, Tragom Ivana Česmičkog u pismima Ivana Viteza od Sredne, Mogućnosti 1-2 (1990), 125-132.

${ }^{26}$ I. Boronkai, Vitéz János az ókori klasszikusok (Ivan Vitez i antički uzori), Budapest 1980.

${ }^{27}$ A. Bonfinis, Rerum Ungaricarum Decades, tomus IV - pars II, 27; D. Dinić-Knežević, Sremski Brankovići, Istraživanja 4 (1975), 8.

${ }^{28}$ A. Bonfinis, Rerum Ungaricarum Decades, tomus IV-pars II, 40.

${ }^{29}$ A. Bonfinis, Rerum Ungaricarum Decades, tomus IV-pars II, 40.

${ }^{30}$ A. Bonfinis, Rerum Ungaricarum Decades, tomus IV - pars II, 48.

${ }^{31}$ Пишући о рату са Пођебрадом, Бонфини наводи како су се, између осталих, у његовој пратњи налазили Емерик, војни заповедник жупаније Сепеш и његов брат Стефан. Њихова оданост и храброст били су од велике користи у предстојећем рату. Он Емерика поистовећује са Одисејем или Паламедом а његовог брата са Агамемноном. 
одметнуо сам се од Матије, али на такав начин да му ни најмање не нашкодим, а себе истовремено сачувам од роварењ а и сплеткарењ а сопствених непријатеља". ${ }^{32}$

У завери су, кратак је писац, учествовали бројни други великаши, али о њима не даје податке. Урота је попримила велике размере. Од укупно 75 жупанија, преостало је само 9 жупанија које су остале верне Матији и наставиле да исплаћују порез. Овај податак Бонфинија често се цитира у историјској литератури. ${ }^{33}$ У завери су, познато је из других историјиских извора, између осталих, учествовали загребачки бискуп Освалд, господар Медведграда Иван, Блаж Подманички, браћа Тузи, Емерих Запоља, Рајналд Розгоњи и многи други.

Нашироко Бонфини говори о разлозима уроте против краља Матије, у којој су се нашли одани и озбиљни људи, пријатељи његовог оца, који то нису учинили из похлепе или лакомислености. По његовом мишљењу, Ивана Витеза од Средне је на издају навела дубока увређеност због чињенице да се краљ у последње време узохолио и осилио. Матија, који је некада умео да да послуша савет великаша и сарадника, сада је игнорисао њихово мишљење и самовољно је владао. Наметање неуобичајено високог пореза (који је представљао оптерећење како за народ у целини, тако и за великаше) додатно је погоршавало ситуацију и премашивало границе издржљивости. Матија је, зарад општег добра, почео да убира приходе и од цркве, уз подршку и помоћ Лавренција Робореле, папаског легата. Од острогонског надбискупа Матија је присвојио десетину од укупног прихода рудника злата - тзв. урбуру, а опорезовао је и немали број других црквених великодостојника. То је нарочито погодило свештенство које је сматрало да на тај начин владар жели да сузбије јачање њиховог слоја. ${ }^{34}$ Интересантно је да Бонфини бележи како је „читав племићки сталеж видео у Матији насилника и тиранина који се више није ни трудио да ту чињенииу сакрије, већ је отворено подразумевао слепу послушност на сваки свој миг". Људи који су некада били сарадници и од великог утицаја на краља, све то су доживели као понижење и тешко су подносили такве промене. На крају, аутор додаје да су све то били по „увреженом мишљењу” разлози који су навели Ивана од Средне и друге великаше на заверу.

Бонфини, не истиче када пише о разлозима уроте, да је велико незадовољство код свих слојева изазвао дуготрајни и исцрпљујући рат са Чесима. Замерали су владару да је вођен искључиво личним амбицијама а нарочито што је занемарио рат против Турака и није спречавао њихов продор на простору Балканског полуострва. ${ }^{35}$ Експанзионистичка политика према Западу Угарској је само доносила нове непријатеље.

\footnotetext{
${ }^{32}$ A. Bonfinis, Rerum Ungaricarum Decades, tomus IV-pars II, 41.

${ }^{33}$ V. Klaić, Povijest Hrvata, od najstarijih vremena do svršetka XIX stoleća IV, 107; П. Рокаи-3. Ђере-Т. ПалА. Касаш, Историја Мађара, Петер Рокаи опрезно констатује, „ако је веровати Бонфинију, од 75 жупанија краљу Матији је остало верно само 9", 164 (П. Рокаи).

34 A. Bonfinis, Rerum Ungaricarum Decades, tomus IV - pars II, 42 „,мматрало се за највећи грех да свештеници и ирквени главари са уобичајеним статусом полубогова на земљи бивају принуђени да се повинују световном надзору”.

${ }^{35}$ P. Hanák, Povijest Mađarske, 51; П. Рокаи-3. Ђере-Т. Пал-А. Касаш, Историја Мађара, 161; Ф. Лонгворт, Стварање Источне Европе, од преисторије до посткомунизма, Београд 2002, 293
} 
На страни угарског краља, од силних племића и сарадника у горњој Угарској, остали су само палатин Михаило и калочки надбискуп. Мудри и увек одмерен у речима, палатин Михаило, по Бонфинију прокоментарисао је наречени догађај следећим речима: „људи су такви да би без поговора и обичног вола штовали као краља, само нека има круну на глави!”.

Учесници завере су се у тајности договорили да за будућег владара изаберу Казимира, млађег сина пољског краља Казимира IV Јагелонца (1447-1492). ${ }^{36}$ Своје намере изнели су у писму које су упутили пољском краљу. У њему су истакли да се целокупно угарско племство одметнуло од Матије, те да су „својевремено непромишљено за свог владара прогласили Корвина, човека незнатног порекла, а да се он убрзо претворио у тиранина јер, будући да није био плаве крви, није ни умео да се носи као краљ". ${ }^{37}$ Матија се, жалили су се они даље, по Бонфинију, окренуо против очевих пријатеља који су га све време чували, поштовали и нису га напуштали ни у највећим невољама и опасностима. Посебно су му замерили што је сопственог ујака, који му је помогао да дође на престо, ухапсио, те на крају и изазвао његову смрт. ${ }^{38}$ Узурпирао је црквену власт, одузимао је приходе од свештенства и ,једном речју, сасвим је изгубио разум". Напослетку, упутилу су молбу Казимиру IV да пошаље сина у Угарску како би примио краљевску титулу. ${ }^{39}$ Одушевељени пољски краљ је одмах припремио сина за пут, доделивши му три легије и најпробранији одред тешке коњице. ${ }^{40}$ Матијин хроничар посебно наглашава како је владар Пољске обавестио острогонског надбискупа и остале

\footnotetext{
${ }^{36}$ Рођен је 1458. у Кракову а умро је 1484. у Гродну. Папа Лав X (1513-1521) прогласио је пољског краљевића 1521. за свеца. Свети Казимир је заштитник Пољске. F. Раре́е, Studia i szkice z czasów Kazimierza Jagillończyka, Warszawa 1907.

${ }^{37}$ A. Bonfinis, Rerum Ungaricarum Decades, tomus IV - pars II, 42.

${ }^{38}$ Бонфини, по трећи пут у свом делу, помиње ујака краља Матије. Наиме, ређајући хронолошким низом догађаје из 1464. и 1465. а пре него што се упустио у описивање устанка у Трансилванији и Молдавији, уметнуо је кратку причу о смрти Михаила Силађија. А. Bonfinis, Rerum Ungaricarum Decades, tomus IV pars II, 11-12. Пише о томе како се Матијин ујак сукобио са Турцима код Пожежене. Иако су непријатељске трупе биле далеко надмоћније, „одвећ частан” Силађи се упустио у борбу. Бонфини зна да му је на почетку сукоба срећа била наклоњена и да су Турци трпели губитке. Иако су их Турци опколили, Силађи је увиђајући опасност и нехајући за свој живот кренуо са неколицином сабораца на најгушће турске редове. На тај начин је ухваћен и одведен у заробљеништво. L.Thallóczy-A. Áldásy, Magyarország melléktartományainak oklevéltára (1198-1526), Budapest 1907, 249-250; На том месту, Бонфини пореди Михаила Силађија и Ђорђа Лабатана. Зна да је Матијин ујак одведен у заробљеништво где је осуђен на смрт декапитацијом. Мехмед II је безуспешно покушавао да од њега добије информације о Београду и Угарској. Ф. Бабингер, Мехмед Освајач и његово доба, Нови Сад 1968, 171; Силађи је погубљен почетком 1461. године. I. Nagy-A. Nyáry, Magyar diplomacziai emlékek Mátyás király korából I, Budapest 1875, 67; М. Динић, Грађа за историју Београда у средњем веку I, Београд 1951, 65-66; Италијански писац, посебно наглашава, да је Матија тешко поднео ујакову смрт сматрајући је губитком за читаво краљевство. Покојног Силађија су, наставља Бонфини, достојно оплакивали сви друштвени слојеви.

${ }^{39}$ A. Bonfinis, Rerum Ungaricarum Decades, tomus IV - pars II, 42. Круна је „својевремено неправедно додељена Матији” и „сада треба да пређе у руке Пољака” како је по речима уротника „одмах и требало да буде".

${ }^{40}$ Исто, 42. Бележи да је пољски краљ „ван себе од радости, захваљивао Богу што му, ето, за само две године два краљевства траже синове за владаре”.
} 
племиће да ће послати сина са најбољим одредима у Угарску. Све то се дешавало у првој половини 1471. године.

Веома брзо, угарски краљ је сазнао за преговоре и долазак младог краљевића у земљу. ${ }^{41}$ Матија је, по Бонфинију, био ван себе од бесе. Није могао да поверује да су се против њега окренули људи, стари очеви пријатељи, које је обасипао пажњом, почастима и даровима. Међутим, решио је да сузбије бес и ослони се на ум. Послужио се мудрошћу и лукавством. Нашао је за то веома добар начин. Решио је да на сваки начин приволи себи оне људе који су се још увек колебали. Великашима је даривао градове и поседе, те је на тај начин успео да их придобије за себе. Он „ниједног тренутка није изгубио веру у себе - у невољама је вазда успевао да задржи присебност и сакупи неку посебну снагу неопходну за будуће, још крупније подвиге”. ${ }^{42}$

Млади Казимир је са 20000 војника 1. новембра 1471. године ушао у Угарску. Свуда је, пише Бонфини, наилазио на сјајну добродошлицу. Многи племићи су долазили да му се закуну на верност, те је логор пољске војске стално растао. У Угарској се осећао као „да је уистину у сопственом краљевству”. ${ }^{43}$ Пошто је прошао Кошице и Егру, логор је померио ближе Нитри и Вацу. Ту је намеравао да прими вође завере са којима је одржавао редовну преписку.

У међувремену, није мировао ни Матија. У Будиму је успео да придобије многе заверенике. Решио је да послуша савет Николе Илочког, да се одмах не сукоби са непријатељима, већ да сачека. Из Будима, Матија је кренуо у Острогон. Намеравао је да придобије, вођу завере, Ивана Витеза од Средне и на тај начин реши цео проблем. Велику пажњу, у свом раду, Бонфини посвећује преговорима угарског краља и острогонског надбискупа. Пошто је Матија у предграђу Острогона подигао војни логор послао је делегацију у утврђење, коју су чинили Емерик Сепешки, палатин Михаило и бројни свештеници да преговарају и приволе на помирење Ивана од Средне. Описујући наступ поменуте делегације, Бонфини у више наврата инсистира на чињеници да је однос између надбискупа и краља, био однос поочима и посинка. Иван је Матији „вазда био попут родитеља”, наступили су посланици. Он га је својим залагањем до престола и уздигао. Уколико му се Матија и замерио „он то очински ваља опростити јер је у великодушној природи родитеља да деци вазда гледају кроз прсте”. Пренели су му Матијине речи „да му не ускраћује негдашњу очинску бригу и приврженост". Говорили су му да завера представља огромну опасност и штету за Угарску и да је најбитнија безбедност и добробит отаџбине. Посебно су истакли да је краља „новонастала ситуащија прилично отезнила", те да се он дубоко каје и обећава да ће се убудуће другачије владати. Матија је учествовао у низу великих подвига те му се провукао и неки лош

\footnotetext{
${ }^{41}$ Бонфини у раду не говори на који је начин краљ Матија сазнао за уроту; V. Klaić, Povijest Hrvata, od najstarijih vremena do svršstka XIX stoleća IV, 106, нап. 108, пише да је пољски краљ послао изасланика загребачком бискупу Освалду Тузу. Он је кренуо на пут преко Аустрије и Штајерске. Из страха се одлучио да у Загреб пошаље два племића која су пала у заробљеништво и краљ Матија је на време дознао за уроту.

${ }^{42}$ A. Bonfinis, Rerum Ungaricarum Decades, tomus IV - pars II, 43.

${ }^{43}$ Исто, 43.
} 
потез. Био је приморан да убира новац за рат и ниједан новчић од прикупљених средстава није узео за себе. Пренели су му краљево обећање да ће испунити сваки разумни захтев и вратити део урбуре који је узео у ратне сврхе. Након ефектног говора, многи су пред острогонског надбискупа пали ничице грлећи му колена.

Потом је уследило Иваново обраћање посланицима. Био је, тврди Бонфини, савладан толиким изливима и одговорио је да никако неће противречити једнодушном ставу угарског племства. Поновио је да се веома ражестио на посинка који се оглушио о црквену власт и узурпирао новац верских главара. Пошто су се бројни саучесници уроте притајили, извесно је да млади пољски краљевић „нема шта више да тражи у Угарској”. Иван је додао да одлично познаје Матију и „краљева је тренутна благост варка и да ће сви они горко платити за издају”. Напослетку, обавезао се на некадашњу послушност а краљеви емисари су исплатили новчану надокнаду за урбуру која је силом изнуђена. На тај начин је заокружен чин помирења између васпитача и ученика, надбискупа и владара, родитеља и сина.

Матији је пао велики камен са срца када је чуо за постигнути договор. Одмах је похитао у Острогон да се нађе са Иваном. Бонфини потом, у себи својственом стилу, доноси говор краља Матије. Сматрајући веома интересантим ово Матијино обраћање некадашњем учитељу преносим га у целини: «Никако, свети мој оче, нисам био кадар да поверујем да ћеш ме од свих људи баш ти напустити! Тешко ми је било да прихватим да си заборавио како ме је рођени отац на самрти управо теби поверио и изгледало је немогуће да ми ти, узор оданости и широкогрудости, тако окренеш леђа. Заједно смо у ланцима тамновали, силне си опасности за моје добро претурио преко главе, из чешког си ме затвора избавио и ти ме на трон узнео - није било ниједног подвига тако недостижног да га уз твоју помоћ и савет нисам могао остварити. Знај да се ни сада Матија, кога си на својим рукама одгајао, неће напустити! Ако сам се у жару младости о тебе и огрешио, опрости ми, племенити оче, смилуј се сину и нека се из твоје тренутне повређености поново расцвета негдашња обострана љубав! Заштити ме сад у невољи, покажи своју уобичајену доброту кад си ме већ својевремено са осталим племићима и изабрао за краља Угарске - управо тако ћеш најбоље испунити завет мом покојном оцу». 44

Инсистирајући на њиховој родитељској љубави, Бонфини пише како су речи краља Матије изазвале код обојице сузе. Прво је острогонски надбискуп пао ничице пред краља и затражио од њега опроштај. Потом су се изљубили а Матија је затражио и добио опроштај за сопствене погрешке. Заклели су се на верност и заборав дотадашњих размирица, успоставили примирје и напослетку се разишли.

Говоркало се, тврди писац, да се током исте ноћи млади Казимир састао са Иваном Витезом и већ наредног дана кренуо са повлачењем. Пољски краљевић се упутио у Нитру где је свечано примљен. И Матија је кренуо пут истоименог града. Истовремено је објавио јавни едикт. Обећао је да ће сви одметници који му се врате у року од три дана бити амнестирани. Пошто је уз помоћ гласника Казимир тајно

${ }^{44}$ A. Bonfinis, Rerum Ungaricarum Decades, tomus IV - pars II, 44-45. 
склопио примирје са угарским владаром, тајно се искрао из Нитре са 700 коњаника и након неколико дана је стигао у Пољску. ${ }^{45}$ Након четири месеца, пољска војска је била у потпуности прогнана а Матија се тријумфално на Свету недељу вратио у Будим.

Дуго размишљајући у Будиму, краљ Матија је донео одлуку да ипак казни преступнике и изгреднике. ${ }^{46}$ Уколико то не учини, сматрао је, неће се дуго одржати на власти. Одлучио је да се најпре разрачуна са главним вођом завере, својим васпитачем, саветником и поочимом. Позвао је Ивана Витеза да дође у Будим зарад неког саветовања. Иако је сматаро да такав сусрет није сасвим безазлен, ипак се радо одазвао „уздајући се у краљеву реч и негдашье блиске односете, те не слутећи евентуалну опасност". Покушавајући, можда, да оправда Иванов пристанак уроти због његовог блиског односа са краљем, Бонфини наводи како је Иван Чесмички увукао ујака против његове воље у заверу. Он се, тврди аутор, последњи придружио завереницма и то на притисак осталих великаша и надасве свог нећака. Наводи да је Иван Витез последњи, и у нади да ће одуговлачењем утицати на остале заверенике да се повуку, потврдио своје присуство састанку са младим Казимиром на Ракошком пољу.

Пошто је стигао у Будим, Иван је уз „третман достојан његовог високог положаја" пребачен у кућни притвор, у вишеградску тврђаву, где је провео неколико месеци. Покушавајући, највероватније, да оправда Матијин поступак, Бонфини наводи како је краља посебно погодила чињеница што га је издао стари очев пријатељ који „му је вазда био попут родитеља”. Поново, бранећи Матију, писац истиче како га је савладала урођена милостивост, сећања на Иванова доброчинства али и бојећи се ружне слике о себи, превазишао је свој гнев и пустио Ивана на слободу. Устоличио га је поново за острогонског надбискупа док се његов учитељ и даље налазио под надзором.

Ближио се крај живота мудрог и ученог Ивана Витеза од Средне. Након беспрекорно честитог и славног живота, под старост је укаљао сопствено име и доживео велико понижење. Он је „буквално вапио за скоријим крајем” те је „држао да ће му смрт донети коначно ослобођење од свих мука и стида". ${ }^{47}$ Упокојио се, како бележи Бонфини, 9. августа, једва дан пре прославе празника Светог Лаврентија. ${ }^{48}$ Његова смрт је изазвала општу жалост.

Од његових заслуга за отаџбину, пошто је описао Витезову смрт, Бонфини кратко наводи да је Угарској завештао сјајну библиотеку са грчким и латинским текстовима. Још је Вергерије подстицао Ивана Витеза, у периоду док је био

\footnotetext{
45 Ускоро је и опкољени остатак пољске војске, уз договор да не причињавају штету по Угарској, напустио опседнути град. Бонфини потом детаљно говори о пљачки и неделима које је ова војска учинила по пољима и селима Угарске.

${ }_{46} \mathrm{O}$ кажњавању чланова уроте након десет година од њеног завршетка погледати опширније рад: В. Krnic, Judicium generale (opći sud) u Ugarskoj i Hrvatskoj, 27-28.

${ }^{47}$ A. Bonfinis, Rerum Ungaricarum Decades, tomus IV - pars II, 47.

${ }^{48}$ Св. Лаврентије (Laurentii) се празнује 10. августа. H. Grotefend, Računanje vremena u nemačkom srednjem i novom veku, Novi Sad 2006, 77, 164-165.
} 
протонотар да сакупља рукописе познатих дела. Претпоставља се да му је он завештао своју библиотеку. ${ }^{49}$ Сакупљање познатих рукописа и књига наставио је Витез у Великом Варадину, где су боравили многи угледни научници. ${ }^{50}$ Свој неуморни културни и књижевни рад наставио је и у Острогону. На његовом двору бораве научници, књижевници, илуминатори, а успостављена је и посебна радионица у којој се вршио препис књига. Ујак и сестрић су основали прве хуманистичке библиотеке у Угарској. ${ }^{51}$

Велику пажњу Бонфини посвећује Витезовом раду на изграђивању и утврђивању Острогона. Он је у тврђави изградио раскошни триклинијум у који се, преко шеталишта украшеног дрворедима, улазило кроз уздигнути наткривени портик од црвеног мермера. Централни део је чинила капелица засвођена у готском стилу и осликана портретима свих дотадашњих угарских краљева, али њихових скитских предака. ${ }^{52}$ Саградио је и купатило са посебним одељцима за топле и хладне купке. Надбискупску палату је преуредио у ренесансном стилу. Иван Витез, је пише Бонфини, највише времена проводио у капели новоподигнуте палате, због прекрсаног погледа на Дунав и још лепшег врта са бујним зеленилом. То место је „било као створено за контемлацију и филозофирање”. 53

Дворски историчар Антоније Бонфини, у свом делу, доноси значајне и занимљиве податке о Ивану Витезу од Средне. Све време инсистира на блискости и родитељској повезаности краља Матије и острогонског надбискупа. У више наврата, напомиње да је он Матијин „поочим”, „родитељ”, „племенити отац” и „старатељ”. Он истиче и хвали Иванове заслуге на политичком, дипломатском и војном плану, које је учинио за отаџбину. Витез је, по Бонфинију, био дубоко одан Матији све до уроте. У даљем тексту, бележи да је острогонски надбискуп последњи приступио завери против угарског владара. За његово учешће, у поменутом догађају, италијански хуманиста оптужује Ивана Чесмичког. Сестрић је „старияа против његове воље и увукао у заверу против Матије”, пише Бонфини.

\footnotetext{
49 Ž. Dadić, Znanstveni i kulturni krug Ivana Viteza u Mađarskoj u 15. stoleću, Mogućnosti 1-2 (1990), 148.

${ }^{50}$ Z. Nagy, Ricerche cosmologiche nella corte umanistica di Giovanni Vitéz, Rapporti Veneto-Ungheresi all'epoca del Rinascimento, Budapest 1975, 65-93.

${ }^{51}$ Опширније погледати: V. Fraknói, Vitéz Janos esztergomi érsek élete, Budapest 1879.

${ }^{52}$ M. Peić, Jan Panonije i slikarstvo, Mogućnosti 1-2 (1990), 133-134.

${ }^{53}$ A. Bonfinis, Rerum Ungaricarum Decades, tomus IV - pars II, 48: „Базилику божанског Алберта Иван је наткрио кровом од посебног стакла отпорног на ватру како би ову грађевину заштитио од киша и снега".
} 
Извори и литература:

Amado, G., La vita e l'opera di Antonio Bonfini, primo storico della nazione ungherese in generale e di Mattia Corvino in particolare, Montalto Marche 1930.

Бабингер, Ф., Мехмед Освајач и његово доба, Нови Сад 1968.

Birnbaum, M. D., Janus Pannonius - Poet and Politician, Zagreb 1981.

Birnbaum, M. D., Humanists in a Shattered World. Croatian and Hungarian Latinity in the Sixteenth Century, Columbus (Ohio) 1986, 48-76.

Bonfinis, A., Rerum Ungaricarum Decades, tomus IV - pars II, ediderunt: Margarita Kulcsar et Petrus Kulcsar, Akademiai Kiado, Budapest 1976.

Boronkai, I., Vitéz János az ókori klasszikusok (Ivan Vitez i antički uzori), Budapest 1980.

Boronkai, I., Iohannes Vitez de Zredna Opera quae supersunt, Akadémiai Kiadó, Budapest 1980.

Gortan, V., Hrvatski latinisti I, Zagreb 1969-1970.

Grgin, B., Počeci rasapa. Kralj Matijaš Korvin i srednjovjekovna Hrvatska, Zagreb 2002.

Grotefend, H., Računanje vremena u nemačkom srednjem i novom veku, Novi Sad 2006.

Dadić, Ž., Znanstveni i kulturni krug Ivana Viteza u Mađarskoj u 15. stoleću, Mogućnosti 1-2 (1990), 147-166.

Динић, М., Грађа за историју Београда у средњем веку I, Београд 1951.

Dinić-Knežević, D., Sremski Brankovići, Istraživanja 4 (1975), 5-47.

Iohannis de Zredna Cancellariae Regis Hungariae olim Prothonotanii Epistolae, in diversis negotiis statum publicum Regni Hungariae concernentibus, ab anno Christi MCDXLV usque ad annum MCDLI etc. per Paulum de Iwanich, dioeceseos Zagrabiensis Presbyterum, altaris S. Pauli in Ecclesia Waradiensi Rectorem et Cancellariae Regiae olim Notarium, in. Schwandtner, Scriptores Rerum Hungaricarum Veteres ac Genuini, vol II, Impensis J. P. Kraus, Bibliopolae Vindobonensis 1746, 3-106.

Jorga, N., Istoria lui Stefan-Cel-Mare, Bucuresti 1904.

Јорга, Н., Историја Румуна и юихове иивилизаиије, Вршац 1934.

Kardos, T., A magyarorszagi humanizmus kora, Budapest 1955.

Kardos, T., Janus Pannonius, Poet of the Hungarian Renaissance, New Hungarian Quarterly 14 (1973), 79-93.

Klaić, V., Povijest Hrvata, od najstarijih vremena do svršetka XIX stoleća IV, Zagreb 1973.

Krnic, B., Judicium generale (opći sud) u Ugarskoj i Hrvatskoj, Vjesnik HAD IX (1906-1907).

I. Kukuljević Sakcinski, Ivan Česmički, Glasoviti hrvati prošlih vjekova, Zagreb 1886, 1-19.

Kurelac, M., Ivan Vitez od Sredne i Jan Panonije (Ivan Česmički) između anarhije i tiranije, Mogućnosti 1-2 (1990), 182.

Kurelac, M., Kulturna i znanstvena djelatnost Ivana Viteza od Sredne, Zbornik Zavoda za povijesne znanosti IC Jugoslavenske akademije 12, Zagreb 1982, 21-34.

Kurelac, M., Hrvatski humanisti rane renesanse, Croatica Christiana periodica 19, Zagreb 1987, $95-$ 107.

Лемајић, Н., Српска елита на прелому епоха, С. Митровица-Источно Сарајево 2006.

Лонгворт, Ф., Стварање Источне Европе, од преисторије до посткомунизма, Београд 2002

Nagy, Z., Ricerche cosmologiche nella corte umanistica di Giovanni Vitéz, Rapporti VenetoUngheresi all'epoca del Rinascimento, Budapest 1975, 65-93.

Nagy-A. Nyáry, I., Magyar diplomacziai emlékek Mátyás király korából I, Budapest 1875.

Pájorin, K., Enea Silvio Piccolomini ed i primi umanisti ungheresi. Rapporti e scambi tra Umanesimo italiano ed Umanesimo europeo, Milano 2001.

Pavešković:A., Priča o jednoj povijesti - Ivan Supek, Buna Janusa Pannoniusa, Republika 49, 9/10 1993, 228-230. 
Papée, F., Studia i szkice z czasów Kazimierza Jagillończyka, Warszawa 1907.

Peić, M., Jan Panonije i slikarstvo, Mogućnosti 1-2 (1990), 133-134.

Perić, O., Zbirka pisama Ivana Viteza od Sredne, Živa antika, god. XXIX, sv. 1, Skoplje 1979, 99111.

Perić, O., Tragom Ivana Česmičkog u pismima Ivana Viteza od Sredne, Mogućnosti 1-2 (1990), 125-132.

Perić, O., Paro, J., Uspon mirnog čovjeka - Ivan Vitez, Zagreb 1979.

Prijatelj, K., Ivan Duknović, Zagreb 1957.

Рокаи, П, Ђере, 3., Пал, Т., Касаш, А., Историја Мађара, Београд 2002.

В. Стефановић, Краљ Матија према Влашкој и Босни, ЛМС, година CVI, књига 331, свеска 13, јануар-март 1932, стр. 173-197.

Teleki, S., Narratio nostra et brevis expositio de vita Iani Pannonii. Iani Pannonii Opusculorum pars altera, Traiecti ad Rhenum, 1784, 161-242.

Tóth, I., Die Genealogie von Janus Pannonius, Acta Litteraria Academiae scientiarum Hungaricae, t. 14, br. 3-4, Budapest 1972, 377-387.

Thallóczy, L., Áldásy, A., Magyarország melléktartományainak oklevéltára (1198-1526), Budapest 1907.

Tuksar, S., Glazbeno-teoretski fragmenti dvaju hrvatskih autora srednjeg veka: Hermana Dalmatinca i Petra Pavla Vergerija, Zbornik radova Četvrtog simpozijuma iz povijesti znanosti, Zagreb 1983, 101-102.

Fraknói, V., Vitéz Janos püspök élete, Budapest 1871.

Fraknói, V., Vitéz Janos esztergomi érsek élete, Budapest 1879.

Hanák, P., Povijest Mađarske, Zagreb 1995.

Huszti, J., Janus Pannonius asztrologiai álláspontja, Minerva (Budapest), 5 (1927), 43-58.

Huszti, J., Janus Pannonius, Péch 1931;

Pongracz, L., Vespasiano da Bisticci ed i suoi clienti ungheresi. Annuario 1 (1939), 229-247.

Ślaski, J., Janus Pannonius et les Polonais, Acta litteraria Academiae scientiarum Hungaricae 15 (1973), 430-435. 


\title{
ABOUT IVAN THE KNIGHT OF SREDNA IN THE OPUS RERUM UNGARICARUM DECADES
}

\begin{abstract}
Summary
The paper follows the narration of Antonio Bonfinius, in the opus Rerum Ungaricarum Decades, Decas IV, on Ivan the Knight of Sredna. The paper is chronologically precisely bounded from the day of coronation of Matthias Corvinus to the day of death of Ivan the Knight of Sredna. News about the Ostrogon Archbishop and a rational humanist are found in the first three books of the aforementioned opus. The first book provides information on the addressing of the King Matthias to Ivan the Knight after the coronation, then on his designation on the position of the Ostrogon archbishop. There were also recorded his activities in relation to the uprising in Transylvania and Moldova, and emphasized his importance as an erudite notary. The second book testifies that in 1468, Ivan was in the Matthew's escort, during the war with the Czechs. The third e book of the opus Rerum Ungaricarum Decades, Decas IV explains in details the conspiracy against the King Matthias, headed by the Ostrogon Archbishop and his nephew. There were listed reasons that led Ivan the Knight of Sredna to join the conspirators, following the course of the conspiracy, his reconciliation with the Hungarian king, and his death. The separate paragraph enumerated the merits of the Knight, which he did in the field of culture for the medieval Hungary.
\end{abstract}

Keywords: Ivan the Knight of Sredna, Antonio Bonfinium, Hungarian King Matthias Corvinus, Ostrogon, conspiracy. 